\title{
男性インポテンスに関する研究
}

\author{
第 VII 報 Visual sexual stimulation を応用した radioisotope penogram \\ による機能的インポテンスと器質的インポテンスの \\ 鑑別診断法に関する研究
}

東北大学医学部泌瓜器科学教室 白 并 将 文
(主任:

\section{STUDIES ON MALE SEXUAL IMPOTENCE}

Differential Diagnosis between Functional and Organic Impotences by Radioisotope

Penogram upon Loading with Visual Sexual Stimulation

Masafumi Shirai

From the Department of Urology, Tohoku University School of Medicine, Sendai

(Director: Prof. S. Shishito)

As the method for objective differentiation between functional and organic impotences, radioisotope penogram with measurement of changes of blood flow through the penis using radioisotope was developed and applied. In the present study, changes of the radioisotope penogram curve were studied upon visual sexual stimulation. In patients with functional impotence, penogram curve rose in response to visual sexual stimulation while in cases with organic disturbance in the nervous system participating in erection including the upper center, penogram curve failed to react entirely despite sexual excitation in response to visual sexual stimulation, making differential diagnosis possible.

\section{緒言}

近年産業の目覚しい発展の犠牲としての学働災害の增 加や交通事故の激增などに伴い勃起神経の損傷例も増加 して抢り，これら症例て対する補償の問題をめぐつてし ばしばトラブルが起こつている. その理由として従来イ ンポテンスの原因が機能的なるのか器質的なるのかの 客観的な鑑別診断法がなかつたことが挙げられる。そ こで著者らは両者の客観的な 鑑別䛦断法として isotope を使用し陰茎内の 血流の変化を観察する radioisotope penogram を開発し応用しており，その成績については 既に本学会雑誌にも発表して来た ${ }^{122)}$.

従来著者が行なつて来た薬物負荷 radioisotope penogram によつて 少なくとも脊髄勃起中枢以下の健在であ るかどらかの判別が 可能になつたが，正常な勃起現象 は周知の如く更に上位中枢のコントロールを受けてお

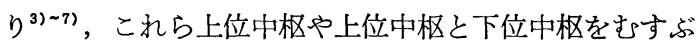

*講 師
連絡路等に器質的障害があるかどうかについては，従来 の検査法では不十分であることが考えられた，そこで著 者は visual sexual stimulationを与えた場合の radioisotope penogram 曲線の変化を観察することにより上位 中枢を含めて勃起に関与する神経系の状態をより正確に 鑑別出来るのではないかと考え以下に述べる如き検査を 行なつてみた。

\section{検查対象並びに検查方法}

最近勃起不全を主訴として当科外来を訪れた32例の患 者を検查対象とした．これら32例の内24例は既往歷並び に現病歴に器質的インポテンスになるべき要因が全く認 められない症例であり, 又6 例は現病歴に外傷等がみら れ, しか子外傷等の後に勃起不全に陥つており, 残る 2 例は既に精神科で精神分裂病及び躁うつ病之診断されて 治療も受けている症例である.

次に検查方法であるが装置は一般に使用されている Renogram 装置 NaI (T1) crystal $2^{\prime \prime} \phi \times 2^{\prime \prime} 1$ (第 1 困) を使用し、コリメーターは陰茎部以外より来る $\gamma$ 線を遮 
第 1 図 4 チャンネル動態記録装置

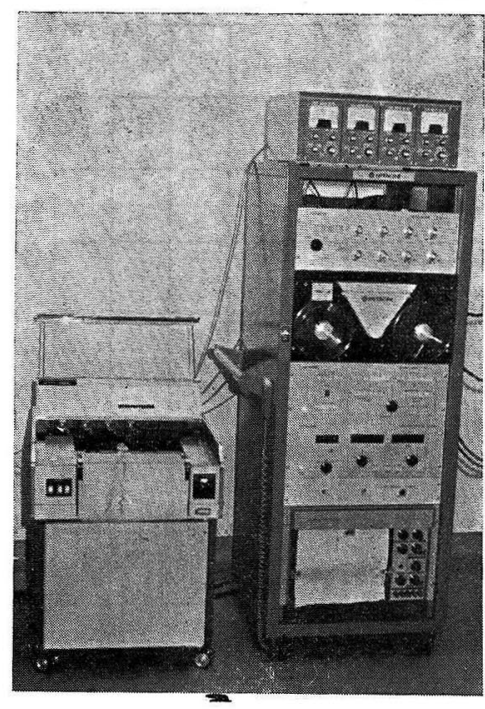

第 2 図 Radioisotope penogram 專用 collimator

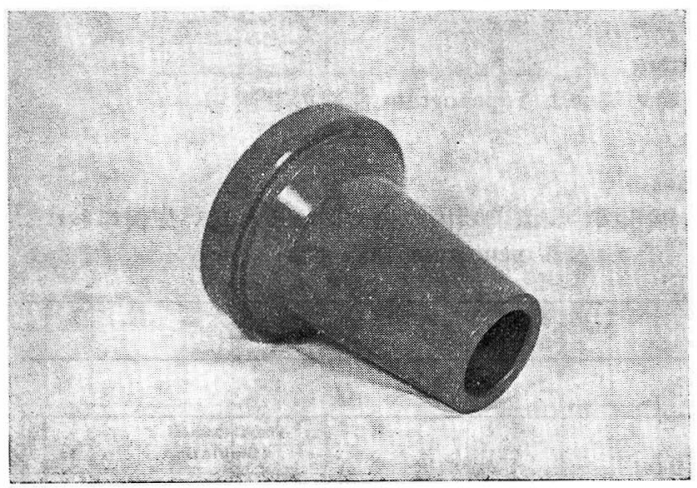

断し計数効率を上げるため本検查専用のものを使用し た（第 2 図），記録紙の送り速度は10 mm/min. であり， 時定数 2 秒，ウインドウ巾 $364 \pm 36.4 \mathrm{KeV}$ である. ま た使用した isotope は ${ }^{131} \mathrm{I}$-人血清アルブミンと ${ }^{113 \mathrm{~m}} \mathrm{In}$ microcolloid であり，その投与量は前者は $50 \mu \mathrm{Ci}$, 後者 は $500 \mu \mathrm{Ci}$ である．尚 ${ }^{131} \mathrm{I}$ 一人血清アルブミンを使用する 場合は検查前に甲状腺が isotope で被曝するのを防止す る目的であらかじめヨウ化ナトリウム液を経口的に投与 した.

患者を仰卧位にしてコリメーターを濾紙でおおい陰茥 を出来るだけコリメーターに入れるよらにした（第 3 図)·をたコントロールとして別のコリメーターを心臓部 及び恥骨部に当て陰茎のバックグラウンドを測定した.

以上のように isotope を投与して陰茥内の血流の変化
第 3 図 Collimator の中に陰荎を挿入する

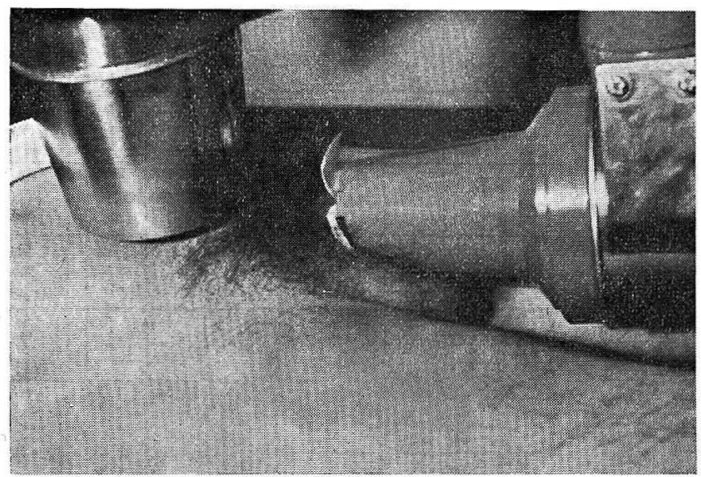

を曲線に書かせ (この曲線を radioisotope penogram と 呼んでいる)，この曲線が平坦になつたところで visual sexual stimulation を与兄, 即ち患者に一定時間 pornographpy を見せて penogram 曲線の変化を観察した. 尚 今回検査した全例に対して前もつて yohimbine 製剤で ある Fujicapin, 含有成分, 本剤 $1 \mathrm{cc}$ 中塩酸ヨヒンビン 3 $\mathrm{mg}$, メチルアルヂン酸ソーダ $8 \mathrm{mg}$, 硝酸ストリキニーネ $0.3 \mathrm{mg}$, ブドウ糖 $18.7 \mathrm{mg}$ 含有されてお゙り, 本剂 $1 \mathrm{cc}$ を皮 下注射する Fujicapin 負荷 radioisotope penogram を施 行しておりこの Fujicapin 負荷 radioisotope penogram とも較検討した.

\section{検查成續}

1）器質的要因の全く認められない症例に打ける penogram 所見

既往歴ならびに現病歴を通して外傷その他器質的要 因と思われる因子が全く部められない24例について penogram を施行した. これら24例のうち23例に対して visual sexual stimulation 負荷 penogrem を施行する前 にあらかじめ Fujicapin 負荷 penogram を施行して拈り いずれの症例も正常なパターンを示した. 即ちFujicapin の投与により penogram 曲線の上昇が全例に認められ た. これら症例に対して或る一定期間の間隔を䇽いて再 び visual sexual stimulation 負荷による penogram を施 行し Fujicapin 負荷 penogram と比較検討した. 又残る 1 例は visual sexual stimulation 負荷を行なら直前に Fujicapin 負荷を行なつてみた.

以上の結果24例中 21 例の penogram曲線で visual sexual stimulation により著明な上昇が認められた. しかもそ の上昇の程度は Fujicapin 負荷 penogram と比較になら ない位著明なるのであつた（第 4,5 図）.しかし残る 3 
第 4 図器質的要因の全く認められない症例に打付る penogram 曲線

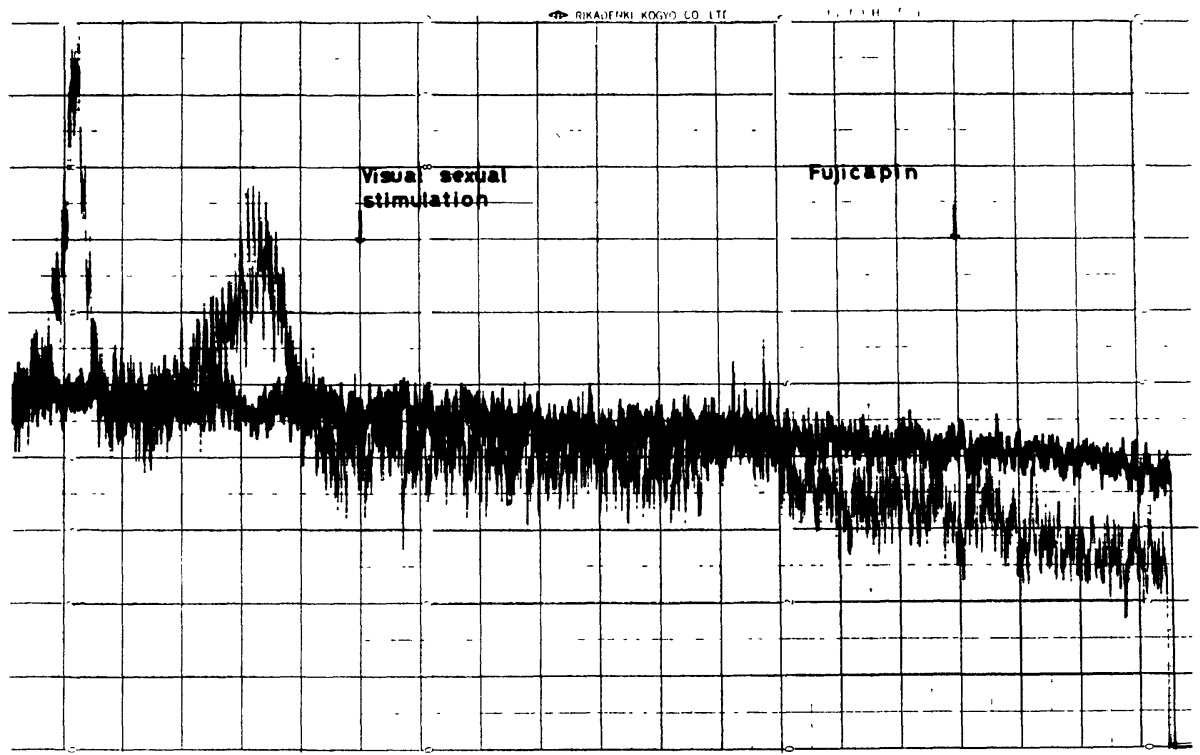

上の曲線はコントロール

下の曲線が penogram

Visual sexual stimulation により Fujicapin 負荷の場合より penogram 曲線の著明 な上昇がみられる。

第 5 図 器質的要因の全く認められない症例におけ る penogram 曲線

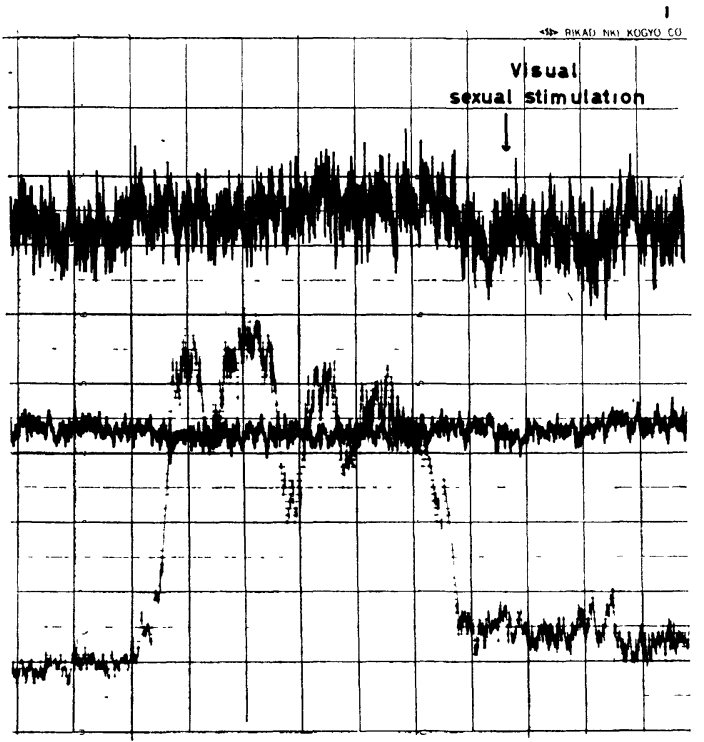

上の曲線は恥骨部の radioactivity 中の曲線は心臓部の radioactivity 下の曲線が penogram

Visual sexual stimulation により penogram 曲線 の著明な上昇がみられる
第 6 四器質的要因の全く認められない症例におけ る penogram 曲線
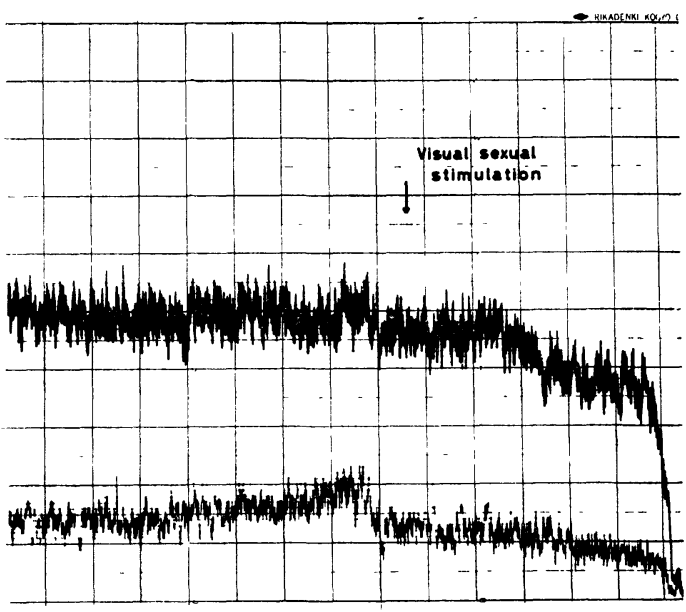

上の曲線はコントロール

下の曲線が penogram

Visual sexual stimulation に対して penogram 曲 線は上昇するが，それ程著明ではない 
第 7 図器質的要因の認められた症例に拈ける penogram 曲線

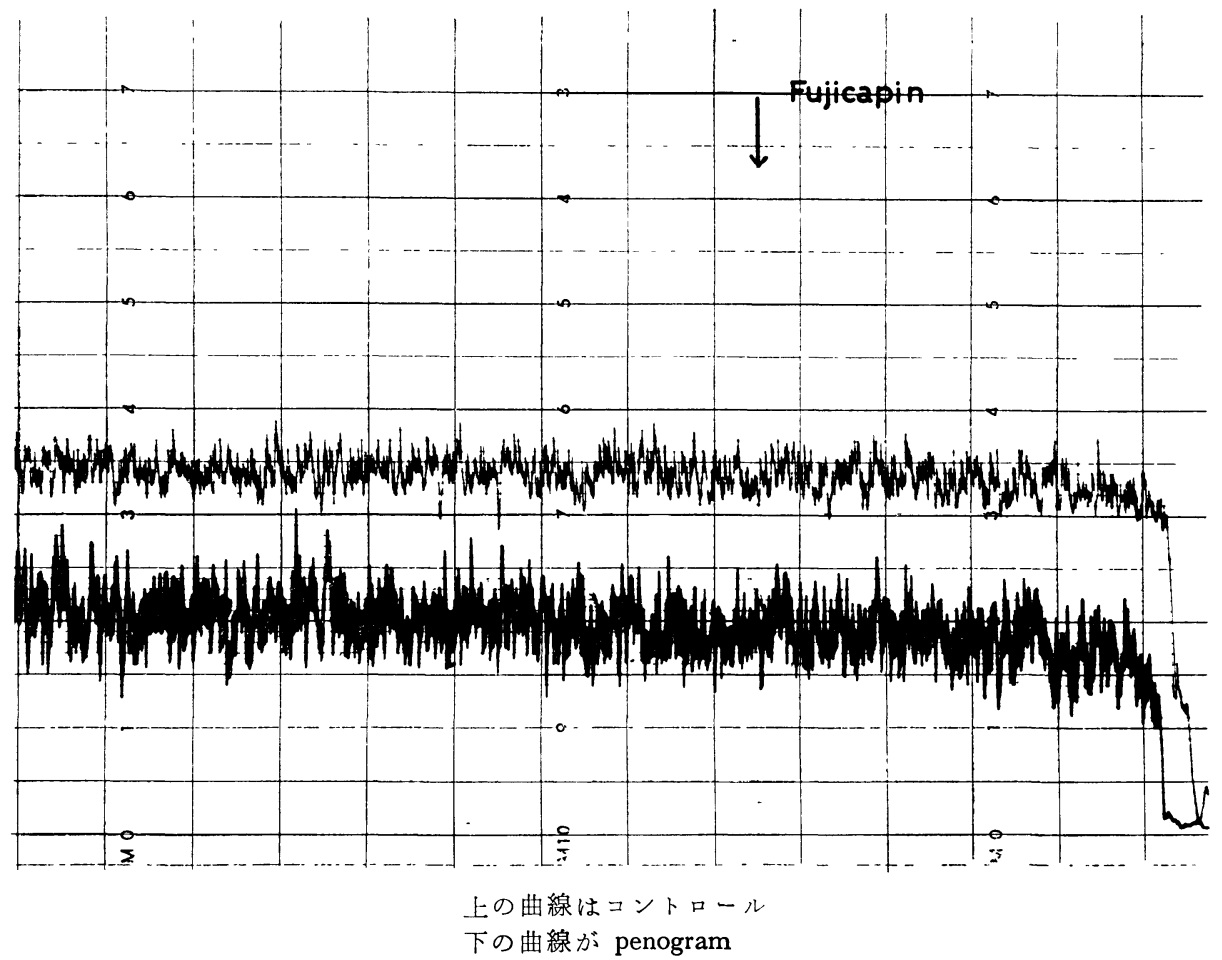

Fujicapin の負荷に対して全く反応を示さない

第 8 図器質的要因の認らめれた症例に打ける penogram 曲線

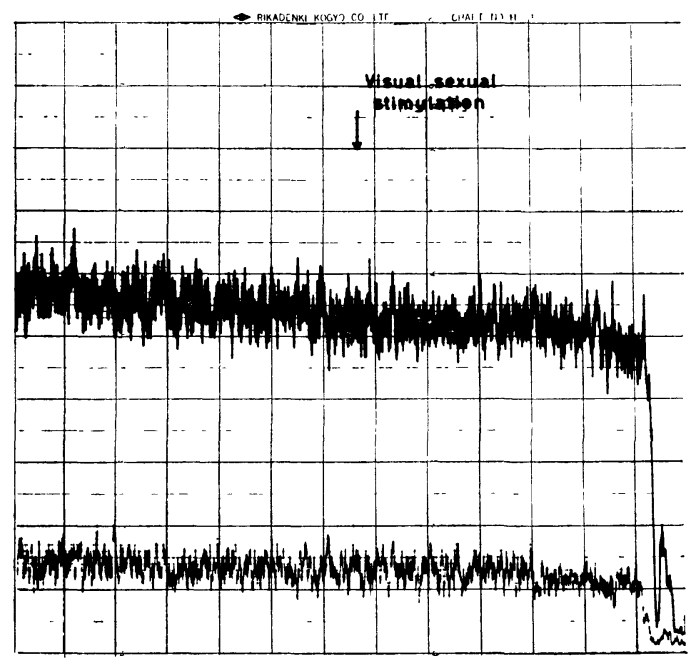

上の曲線はコントロール

下の曲線が penogram

Visual sexual stimulation に対しても全く反応が みられない
第 9 図精神病性インポテンス症例の penogam 曲 線(躁うつ病患者)

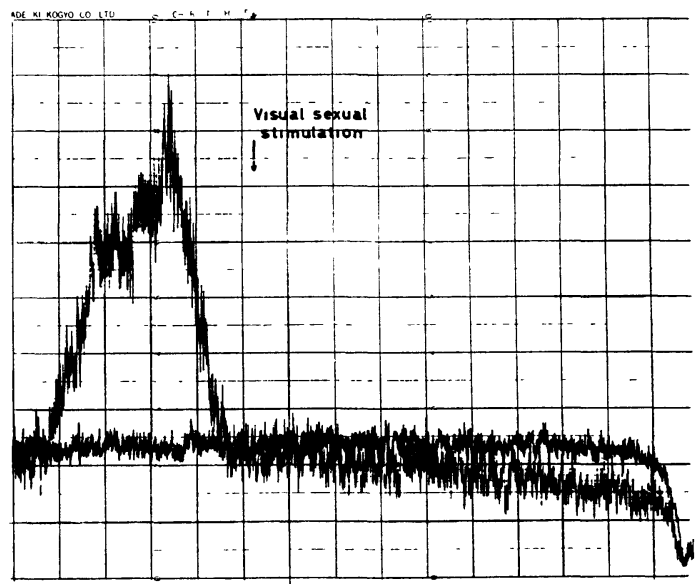

上の曲線はコントロール

下の曲線が penogram

Visual sexual stimulation で penogram 曲線の著 明な上昇がみられる 
例では, penogram 曲線の上昇が他の 21 例に 比して著明 ではなくほぼ Fujicapin 負荷 penogram と同程度の上昇 であつた（第 6 図）.

2）器質的要因の認められる症例に和ける penogram 所見

今回は 6 例のみであるが，いずれ，交通事故で頭部外 傷並びに全身打撲の後にインポテンスになつて扔りその らち 3 例は Fujicapin 負荷によつても penogram 曲線の 上昇はみられず, visual sexual stimulation 負荷に対し ても全く曲線の上昇はみられなかつた（第 7,8 図）.し かし他の 3 例は曲線の上昇がみられた。 またこれら 6 例 共 visual sexual stimulation に対して強い性的興奮は感 じたと訴劣ている。

3）精神病に起因すると思われる症例における penogram 所見

今回は精神科に损いて既に精神分裂病と躁らつ病と診 断され現在も治療を受けている患者であり,これら 2 症 例共に現在は平穏状態にある.これら 2 症例に対して先 づ Fujicapin 負荷 penogramを施行したが，いずれも反 応がみられ, 即ち penogram曲線の上昇がみられ, visual sexual stimulation に対しても2 例共著明な penogram 曲線の上昇が認められた（第 9 図）。

\section{考 按}

勃起は, 視覚, 聴覚, 嗅覚, イメージなど大脳性の刺 激等が間脳性勃起中枢を興奮させ, その刺激が脊髄勃起 中枢を興奮させて勃起するいわゆる erotic erection と， このような性的與奮を伴わない，例えば膀胼充満時にみ られるような上位中枢とは無関係な脊䯣中枢反射で起こ るいわゆる reflective erection に区別される. この反射 性勃起の存在は脊䯣勃起中权以下の健全なことを示す一 つの指標として臨床的に重要である. しかし正常な勃起 現象にはこれら下位勃起中枢以下が健全であるのみでな く高位勃起中枢並びにその連絡路が健全でなければなら ない. 即ち勃起現象そのものは先にも述べた如く低位脳 幹中枢と金髄中枢とで統合される一連の反射からなつて 打り, これら勃起に随伴する性行動の大部分は辺縁系と 視床下部により調節されているが，新皮質も性行動に関 与して招り，特に前頭葉の損傷の場合に性行動が抑制さ れることが知られている. また側頭葉, 特に扁桃核とと れに関連した梨状葉の一部は性行動に対して強い抑制作 用を有しており，この部の破壊により過剩性行動が出現 することが認められている ${ }^{8}$. またこれらの過剩性行動 を誘起する辺縁系と神経線維連絡上密接な関係をるつ皮
質後帯状回, 海馬の一部の刺激により勃起が起こること も知られている ${ }^{910)}$. このように性行動は神経系の多数 の部位が関係する極めて複雑な生理現象と云うことが出 来る. 従つて正常な性行動が行なわれる為にはこれらの いずれの部位も正常でなければならないわけである.

さて機能的インポテンスと器質的インポテンスの客観 的な鑑別診断法として著者らは先にも述べた如く薬物投 与, 即ち Fujicapin の負荷により陰茎内の血流の変化を 観察する，いわゆる Fujicapin 負荷 penogram により少 なくとも下位勃起中枢以下に器質的な障害があるかどう かの鑑別が出来るようになつたが，この方法のみでは上 位中枢の状態を知ることは不可能であつた，そこで著者 は Fujicapin 負荷による penogram を行ならと同時に visual sexual stimulationを与文た際の陰茎内の血流の 変化を観察することにより上位中枢の状態を知らんと試 みた.

このように著者が上位中枢の状態を知る為に visual sexual stimulationを特に選んだ理由は，Kinsey ら ${ }^{11}$ に よれば男性は女性の場合と比較して視覚刺激により性的 興奮を強く引起こすと述べて括り, 更に Levi ${ }^{12)}$ は53例 の女子学生と50例の男子学生に対して各種の性的フイル ムを見せて，即ち visual sexual stimulation を与えてそ の際の性的興荠の起こる状態と尿中の adrenaline 及び noradrenaline を測定したところ尿中 adrenaline 及び noradrenaline の排泄量はコントロール群に比して両性共に 著明な增加を示し, しかも男性群がより著明であり,ま た性的興奮の状態でも全く性的興奮を感じかつたと答 えたものが女性群には $21 \%$ もたたに対して男性群では わずか $4 \%$ のみであつたと述べており，これらのことよ り Levi は男性では視覚刺激により性的與翼が引起こさ れるとする Kinsey らの説が正しいと述べている.この ように visual sexual stimulationを与えることが男性に とつては性的興奮を起こさせる最も適切な方法と考えら れたので著者も visual sexual stimulation を与えた際の 陰茎内の血流の変化を観察することにしたわけである.

先ず器質的要因の全く認められない症例においては 24例中21例に visual sexual stimulation により著明な penogram 曲線の上昇が認められたが， 3 例は曲線の上 昇が著明ではなく Fujicapin 負荷 penogram と同程度の 上昇が認められた.これらの症例が他の症例に比して何 故 penogram 曲線の上昇が悪かつたかを検討してみたと ころ, これらの症例は著者らが患者に供覧した pornography 々同様の pornography を以前にも何度も見てお 
ク，今回の pornography の供覧によつても何等の性的興 奮も感ぜず，むしろ嫌悪感すら括洼えたと訴えており， visual sexual stimulation を与える場合，このような刺 激に対する慣れの現象を十分考慮する必要性があるし， また同じ visual sexual stimulationを与えても, 患者の 教養程度とか，宗教とか，その他あらゆる社会的な条件 によつてその性的反応も異つて来ることに注意しなけれ ばならない。

一方性的興奮により心搏出量が增加し，その為に陰茎 内の血流量が増加し penogram 曲線の上昇をきたすこと も考光られたが，これはコントロールとしてコリメータ 一を恥骨部のみでなく心臓部にも当ててみたが，これら コントロール曲線は visual sexual stimulation によつて も全く変化がみられなかつたことより,この点について は否定することが出来た.

以上のようにとにかく神経系統に器質的異常のみられ ない症例では多かれ少なかれ penogram 曲線上に反応が みられると云うことが判つた.

次に器質的要因の認められた症例に打ける penogram では 6 例中 3 例は visual sexual stimulation に対して全 く反応を示さなかつた. しかしこれら症例はいずれる pornography の供覽により強い性的興奮を打涪えたと訴 えており，このように器質的障害が考えられた症例にお いてはいかに性的興奮が起つても penogram 曲線上には 何等の変化も認められず, penogram 上の変化は神経系 を介する刺激によつてのみ起こるものと考兄られた，即 ち Levi らが云うように visual sexual stimulation によ り性的興奮が起こり adrenaline や noradrenaline の分泌 がいかに高まつても penogram 曲線上に何等の変化も現 れなかつたことより，これらの物質がいかに分泌されて も勃起に関与する神経系が健全でなければ penogram 曲 線上全く変化が現れないことが判つた.

一方 6 例中 3 例に反応がみられ，一見外傷等による器 質的インポテンスのように思われる症例でも本検查によ り鑑別が可能であることが判つた。

さらに反応のみられなかつた 3 症例では共にFujicapin 負荷によつても penogram 曲線上全く反応がみられなか つたことより，本当に上位中枢のみが障害されていたか どうかは不明であると共に Fujicapin そのものが下位中 权のみに作用するのではなく上位中权にもかなりの比重 をもつて作用していることが考えられたが現在のところ その作用機序及び作用部位等については正確な事が判つ ていない，乙かし将来，上位中枢に明らかな障害が認め
られ，しかも visual sexual stimulation により性的興奮 を陉㜔えるような症例で Fujicapin 負荷 penogram に は反応するが visual sexual stimulation 負荷 penogram には全く反応を示さないような症例がみられるならば Fujicapin が下位钦起中枢に作用することが証明される ことになるが，現在のところはこれらの方法では器質的 障害の有無は鑑別出来てもその障害部位までは鑑別は不 可能である.

しかし著者らの知りたいのは器質的インポテンスか機 能的インポテンスかの鑑別であり，少なくともFujicapin 負荷 penogram 之visual sexual stimulation負荷penogram の併用によりこれらの目的は十分はたせることが判つ た.

最後に精神病性インポテンスに対する visual sexual stimulation による penogram であるが， 2 例共に著明 な曲線の上昇が認められた．しかしこれら 2 例は共に現 在著者らが接した範囲では正常な精神状態にあり visual sexual stimulation により性的興奮を感じているが，分 裂病や躁うつ病，特にうつ病期においては全く性欲が衰 失すると言われており，このような場合に visual sexual stimulation による penogram を行なつてもはたして反 応を示すかどうかははなはだ疑問である，従つてこのよ らな場合は先にも述べた如く Fujicapin 負荷 penogram を併用すべきである．即ち性欲は androgen の高度に欠 乏した性交不能な老人にあつてもな和存在するし, 又 Talbot ${ }^{13)}$ は脊髄損傷で勃起や射精の全く不能な症例でも な打存在することを認めており，これらの事実は性欲そ のものは心理的，精神的なものであること示しており， ヒトに执いては本能とかホルモン等の統御を比較的受け なくなつているものと考えられる．従つてごく限られた 疾患々者を除いては visual sexual stimulation に対し て何等かの反応を示すと考えられるが Fujicapin 負荷 penogram を併用する方がより確実と言える.

以上の如く機能的インポテンス症例では visual sexual stimulation により penogram 曲線の上昇がみられるの に対し，上位中枢を含む勃起飞関与する神経系に器質的 障害がある場合には visual sexual stimulation を行なつ ていかに性的興奮を引起こしても penogram 曲線上全く 反応はみられないことが判つた。 しかし visual sexual stimulatio に対する感受性は個人によつて全く異なるこ とが予想され，又疾患によつては visual sexual stimulation に対して全く性的興奮を引起こさないことも考慮 し Fujicapin 負荷 penogramを同時に行なう必要があ 
り，両検査法を併用することにより器質的インポテンス と機能的インポテンスの客観的鑑別診断がより確実に出 来ることが判つた。

\section{結語}

著者は機能的インポテンスと器質的インポテンスを客 観的に鑑別する方法として isotope を使用して陰茎内の 血流の変化を測定する radioisotope penogram を開発利 用しているが，今回は visual sexual stimulationを与兄 た場合の radioisotope penogram 曲線の変化を観察し た. その結果機能的インポテンス患者では visual sexual stimulation により penogram 曲線の上昇がみられるの に対し，上位中枢を含も勃起関与する神経系に器質的 な障害がある症例ではvisual sexual stimulationによりい かに性的興奮が起つても penogram 曲線上全く反応は みられず両者の鑑別が可能であることが判つた. しかし visual sexual stimulation に対する感受性は個人差があ り，又疾患によつては visual sexual stimulation に対し て全く性的興奮を引起こさないこともあるので，従来著 者らが行なつて来た薬剤負荷による penogram を併用す れば両者の鑑別がより確実に出来ることが判つた。

（稿を終るに臨み御賏篤なる御指導と御校閲を賜つた 恩師宾戸仙太郎教授に心上り感謝致します。又終始御協 カ下さいました本学故射線医学教室中村護講師に感謝致
します，尚本研究は文部省科学研究費の援助によつて行 なわれた事を明記し感謝の意を表します)。

\section{文献}

1）白非将文：日泌尿会誌，62，147，1971.

2) 白井将文：日泌尿会誌，62，700，1971.

3) Beach, F.A.: Physiol. Rev., 27, 204, 1947.

4) Bors, E. \& Comarr, E.: Urol. Survey, 10, $191,1960$.

5) Meyers, R.: Trans. Amer. Neurol. Ass., 86, 81, 1961.

6) Symonds, C.P.: Concusion and contusion of the brain and their sequelae. Injuries of skull and spinal cord, Williams \& Wilkins Co., Baltimore, 1940.

7) Vaughan, E. \& Fisher, A.E.: Science, 137, 758, 1962.

8) Kluver, H. \& Bucky, P.C.: Arch. Neurol. Psychiat., 42, 979, 1939.

9) Mac Lean, P.D., et al.: Physiol. Rev., 40, (Suppl. No. 4) 105, 1960.

10) Mac Lean, P.D.: Amer. J. Med., 25, 611, 1958.

11) Kinsey, A.C., et al.: Sexual behaviour in the human female. Saunders, Philadelphia, 1953.

12) Levi, L.: Psychosomatic Med., 31, 251, 1969.

13) Talbot, H.: J. Urol., 73, 91, 1955.

（1973年 3 月 22 日受付） 